\title{
AKTIVITAS ANTIBIOFILM FRAKSI ETIL ASETAT EKSTRAK DAUN PUTRI MALU (Mimosa pudica) PADA BAKTERI METHICILIN-RESISTANT Staphylococcous aureus (MRSA) SECARA IN VITRO
}

\author{
Sri Winarsih ${ }^{\star 凶}$, Uswatun Khasanah ${ }^{* *}$, Abu Hasan Alfatah**
}

\begin{abstract}
Abstrak
Methicillin-Resistant Staphylococcus aureus (MRSA) merupakan salah satu bakteri yang dapat membentuk biofilm. Biofilm dapat menghambat kerja antibiotik sehingga dapat menyebabkan resistensi antibiotik. Daun putri malu (Mimosa pudica) memiliki senyawa metabolit sekunder di antaranya yaitu senyawa flavonoid. Senyawa flavonoid yang didapatkan dari fraksi etil asetat daun Mimosa kemungkinan dapat memberikan efek merusak biofilm sekaligus antibakteri bagi bakteri MRSA. Senyawa flavonoid dapat diperoleh melalui proses fraksinasi menggunakan pelarut etil asetat. Penelitian ini bertujuan untuk mengetahui pengaruh pemberian fraksi etil asetat terhadap kerusakan biofilm dan terhadap jumlah koloni bakteri, berdasarkan lama inkubasi. Dosis fraksi etil asetat yang digunakan yaitu $3 \mathrm{mg}, 6 \mathrm{mg}, 9 \mathrm{mg}, 12 \mathrm{mg}$, $15 \mathrm{mg}$. Lama inkubasi yang digunakan yaitu satu jam dan dua jam. Jumlah koloni bakteri dihitung menggunakan skor. Skor tertinggi +6 untuk pertumbuhan koloni bakteri yang sangat padat dan skor terendah +1 untuk pertumbuhan koloni bakteri yang renggang. Hasil penelitian menunjukkan bahwa besar kerusakan biofilm seiring dengan dosis fraksi etil asetat (Spearman, $r=0,426, p=0,01$ ), dan besar kerusakan perlakuan waktu 2 jam lebih tinggi dari pada perlakuan 1 jam (Paired $t$ test, semua dosis menunjukkan $p<$ 0,00 ). Jumlah koloni menunjukkan penurunan, namun tidak ada perbedaan bermakna antara waktu 1 jam dengan 2 jam (Paired $t$ test, semua dosis $p>0,00$ ). Kesimpulan pada penelitian ini adalah fraksi etil asetat dari ekstrak daun putri malu (Mimosa pudica) dapat merusak biofilm dari bakteri MRSA, dan perlakuan waktu 2 jam menunjukkan kerusakan yang lebih tinggi dari pada 1 jam, namun tidak ada perbedaaan dalam menurunkan jumlah koloni MRSA yang berada dalam lapisan biofilm antara waktu 1 jam dan 2 jam.
\end{abstract}

Kata kunci: bakteri MRSA, fraksi etil asetat, kerusakan biofilm, Mimosa pudica.

\section{ANTIBIOFILM ACTIVITY OF ETHYL ACETIC FRACTION OF Mimosa pudica LEAF EXTRACT ON METHICILLIN-RESISTANT Staphylococcous aureus (MRSA) BACTERIA IN VITRO}

\begin{abstract}
Methicillin- Resistant Staphylococcus aureus (MRSA) is one of the bacteria that produces biofilm. Biofilm inhibits antibiotics contact with bacteria causing antibiotic resistance. Mimosa leaves contains secondary metabolites that includes flavonoids. Flavonoid compounds obtained from the ethyl acetate fraction of Mimosa leaves may have the detrimental effect biofilms as well as antibacterials effect for MRSA bacteria. Flavonoid compounds can be obtained through the fractionation process using ethyl acetate solvents. This study aims at determining the effect of ethyl acetic fraction administration on biofilm degradation level and on the number of bacterial colonies, based on incubation time. The dose of ethyl acetate fraction used were $3 \mathrm{mg}, 6 \mathrm{mg}, 9 \mathrm{mg}, 12 \mathrm{mg}$, and $15 \mathrm{mg}$. The incubation time used were one hour and two hours. The dose of ethyl acetate fraction used were $3 \mathrm{mg}, 6 \mathrm{mg}, 9 \mathrm{mg}, 12 \mathrm{mg}$, and $15 \mathrm{mg}$. The incubation time used were one hour and two hours. The number of bacterial colonies was calculated using a score. The highest score was +6 for high density bacterial colonies and the lowest score was +1 for the lowest density bacterial colonies. The results showed that biofilm degradation level increased along with the increasing dose of ethyl acetate fraction (Spearman, $r=0.426, p=0.01$ ), and degradation level on 2 hours treatment was higher than 1 hour treatment (Paired $t$ test, all doses showed $p<0,00$ ). There was a reduction in the number of colonies demonstrated, however the difference between the time of 1 hour and 2 hours was insignificant (Paired $t$ test, all doses showed $p>0.00$ ). The conclusion of this study is that ethyl acetic fraction from Mimosa pudica leaf extract capable to degrade biofilm produced by MRSA bacteria, and the rate of degradation is higher in 2 hours treatment compared to those of 1 hour, but no significant difference effect on decreasing colonies number of MRSA in the biofilm layer was found between the two treatments.
\end{abstract}

Keywords: biofilm degradation, ethyl acetict fraction, Mimosa pudica, MRSA bacteria.

* Departemen Mikrobiologi, Fakultas Kedokteran, Universitas Brawijaya

** Jurusan Farmasi, Fakultas Kedokteran, Universitas Brawijaya

区-mail: wiensri238@gmail.com 


\section{Pendahuluan}

Methicilin-Resistant Staphylococcus aureus (MRSA) merupakan bakteri bentuk kokus Gram positip yang bersifat resisten terhadap berbagai jenis antibiotika, dan menjadi masalah yang serius di negara maju maupun di negara sedang berkembang seperti Indonesia. ${ }^{1,2}$ MRSA adalah salah satu bakteri pembentuk biofilm. Bakteri penyebab infeksi mampu mempertahankan diri dengan membentuk suatu pelindung atau lapisan yang disebut biofilm. Biofilm merupakan salah satu produk hasil interaksi quorum sensing (QS) dari masing-masing organisme sehingga dapat membentuk suatu lapisan akibat dari penempelan bakteri pada permukaan yang cocok. Adanya biofilm tersebut menyebabkan antibiotika tidak dapat mencapai target kerja pada sel bakteri, sehingga bakteri penyebab infeksi tidak dapat dieradikasi. ${ }^{3}$

Putri malu (Mimosa pudica) merupakan tanaman yang mudah tumbuh dan berpotensi untuk dimanfaatkan sebagai antimikroba. Potensi Mimosa untuk mencegah pembentukan biofilm sudah diteliti, namun belum terdapat penelitian terkait perusakan biofilm. Salah satu senyawa yang terkandung dalam daun putri malu adalah senyawa flavonoid golongan flavon dan flavonol. ${ }^{4}$ Ekstrak dari tanaman yang memiliki senyawa metabolit sekunder flavonoid memiliki potensi menghambat intercellular adhesion genes icaA dan icaD. Adanya gen ica $A$ dan icaD pada bakteri menjadi salah satu faktor dari pembentukan biofilm. ${ }^{5}$ Disebutkan bahwa gugus hidroksil yang dimiliki struktur senyawa flavonoid dapat menyebabkan pembentukan senyawa kompleks dengan protein yang dapat mengakibatkan biofilm terdenaturasi. ${ }^{6}$

Senyawa flavonoid dapat diisolasi menggunakan pelarut etil asetat melalui fraksinasi terhadap ekstrak tanaman. Penelitian dengan menggunakan fraksi memiliki kelebihan dibandingkan ekstrak karena pada fraksi akan terkandung jumlah senyawa yang lebih sedikit sehingga dapat dioptimalkan senyawa yang diharapkan memberikan efek.

Penelitian ini bertujuan membuktikan bahwa fraksi etil asetat ekstrak daun putri malu (Mimosa pudica) dapat merusak biofilm dan sekaligus membunuh MRSA pembentuk biofilm secara in vitro. Hasil penelitian diharapkan menjadi dasar penemuan obat baru yang dapat merusak biofilm sehingga dapat digunakan secara komplementer bersama antibiotika atau bahkan mungkin dapat digunakan sendiri tanpa antibiotika karena mampu merusak biofilm sekaligus. membunuh bakteri.

\section{Bahan dan Metode}

\section{Alat dan Bahan}

Alat yang digunakan dalam penelitian ini yaitu neraca analitik (OHAUS CP214), Oven (Memmert UN 55), rotary evaporator (IKA ${ }^{\circledast}$ RV 10 basic), pompa vakum (Vacuubrand $^{\circledR}$ ), sonikator (Sonica ${ }^{\circledR}$ ), Vortex, Spektrofotometer, Cakram sefoksitin, Mikroskop, Microplate Reader (Biozatix ${ }^{\circledR}$ ).

Simplisia daun putri malu (Mimosa pudica) diperoleh dari UPT. Materia Medica Batu. Sampel bakteri MRSA berjumlah 4 isolat $(A, B, C, D)$ berasal dari luka terinfeksi (dari empat penderita yang berbeda) dan merupakan bakteri yang disimpan oleh Laboratorium Mikrobiologi FKUB. Bahan lainnya adalah: akuades, etanol $96 \%$, DMSO, Nutrient Agar, Nutrient Broth, $\mathrm{NaCl}$ $0,9 \%$, kit pewarnaan Gram, plat Staphaurex, larutan $\mathrm{H}_{2} \mathrm{O}_{2}$, Trypton Soy Broth-Glu (TSBglu), Phosphate Bufferd Saline (PBS), Isopropanol $\mathrm{HCl}$.

\section{Ekstraksi Maserasi Daun Putri Malu}

Sebanyak 300 gram serbuk simplisia daun putri malu dimasukkan ke dalam toples kaca, dicampurkan etanol $96 \%$ sebanyak 3 
L. Diaduk dengan stirrer kecepatan $400 \mathrm{rpm}$ selama 30 menit. Didiamkan 1x24 jam, campuran disaring dan filtrat yang disimpan. Residu dimaserasi tiga kali dengan etanol $96 \%$ sebanyak $3 \mathrm{~L}$ selama $3 \times 24$ jam. Disaring dan dicampurkan dengan filtrat hasil maserasi pertama. Selanjutnya filtrat di pekatkan dengan rotary evaporator pada suhu $40 \pm 2{ }^{\circ} \mathrm{C}$ kecepatan $70 \mathrm{rpm}$ hingga pelarut menguap, dilanjutkan pengeringan menggunakan oven pada suhu $40 \pm 2$ ${ }^{\circ} \mathrm{C}$. Hasil ekstrak kental ditimbang dan dihitung persen rendemen menggunakan rumus:

$$
\% \text { rendemen }=\frac{\text { berat akhir }}{\text { berat awal }} \times 100 \%
$$

\section{Fraksinasi Ekstrak Daun Putri Malu}

Ekstrak etanol daun putri malu ditimbang 20 gram. Disuspensikan dalam akuades $100 \mathrm{ml}$. Dimasukkan ke dalam corong pisah, ditambahkan n-heksana 100 $\mathrm{ml}$. Dikocok selama 5 menit, sesekali gas dikeluarkan, diamkan hingga terbentuk dua lapisan. Dipisahkan lapisan yang terbentuk. Proses diulang hingga fraksi $n$-heksana menjadi jernih atau warna terlihat konstan. Residu fraksi n-heksana ditambahkan dengan $100 \mathrm{ml}$ etil asetat, dikocok selama 5 menit, sesekali gas dikeluarkan, diamkan hingga terbentuk dua lapisan. Kemudian dipisahkan, prosedur diulang hingga fraksi etil asetat menjadi jernih atau warna terlihat konstan. Fraksi dipekatkan dengan rotary evaporator pada suhu $40 \pm 2{ }^{\circ} \mathrm{C}$ kecepatan 70 rpm hingga pelarut menguap, dilanjutkan pengeringan menggunakan oven pada suhu $40 \pm 2{ }^{\circ} \mathrm{C}$. Hasil fraksi kental ditimbang dan dihitung persen rendemen menggunakan rumus:

$\%$ rendemen $=\frac{\text { berat akhir }}{\text { berat awal }} \times 100 \%$

\section{Identifikasi Bakteri Bakteri MRSA \\ Pewarnaan Gram:}

Koloni bakteri diambil menggunakan ose, diletakkan pada gelas objek. Difiksasi kemudian diteteskan larutan kristal violet, diamkan selama 1 menit. Dibilas dengan air mengalir. Diteteskan lugol, diamkan selama 1 menit. Dibilas dengan air mengalir. Diteteskan alkohol $96 \%$ sampai luntur. Dibilas dengan air mengalir. Diteteskan safranin, diamkan selama 30 detik. Dibilas dengan air mengalir. Dikeringkan dengan kertas penghisap, setelah kering ditetesi minyak emersi diamati menggunakan mikroskop dengan perbesaran 1000kali. MRSA merupakan bakteri Gram positif (berwarna ungu) berbentuk kokus.

\section{Uji katalase:}

Koloni bakteri pada gelas objek disuspensikan dengan akuades steril. Ditambahkan larutan $\mathrm{H}_{2} \mathrm{O}_{2}$, kemudian diamati reaksi yang terjadi, dikatakan positif apabila terdapat gelembung udara.

\section{Uji koagulase:}

Koloni bakteri diambil menggunakan ose. Digoreskan pada plat Staphaurex. Ditambahkan reagen Staphaurex. Diamati reaksi yang terjadi, dikatakan positif apabila terjadi penggumpalan atau aglutinasi.

\section{Uji sensitivitas sefoksitin:}

Suspensi bakteri diinokulasi pada permukaan media Nutrient Agar, kemudian diberikan cakram sefoksitin $30 \mu \mathrm{g}$. Diinkubasi $37^{\circ} \mathrm{C}$ selama 18 jam. Dihitung diameter zona hambat yang terbentuk. Jika zona hambat yang terbentuk $\leq 21 \mathrm{~mm}$, maka dikatakan positif bakteri MRSA. ${ }^{7}$

\section{Pembuatan Suspensi Bakteri}

Setelah diidentifikasi sebagai bakteri MRSA, disiapkan bakteri $10^{6} \mathrm{CFU} / \mathrm{mL}$ menggunakan spektrofotometri panjang gelombang $625 \mathrm{~nm}$. Optical Density (OD) = 0,1 setara dengan kepadatan sel bakteri $10^{8}$ $\mathrm{CFU} / \mathrm{mL} .^{8}$ 
Dosis Fraksi Etil Asetat Ekstrak Daun Mimosa

Ditimbang fraksi etil asetat sebanyak $75 \mathrm{mg}$ dan dilarutkan dengan $1 \mathrm{~mL}$ DMSO $10 \%$ sehingga didapatkan konsentrasi 75 $\mathrm{mg} / \mathrm{mL}$. Selanjutnya dilakukan pengenceran bertingkat untuk mendapatkan dosis larutan uji untuk setiap $200 \mu \mathrm{L}$ adalah $15 \mathrm{mg} / \mathrm{mL}, 12$ $\mathrm{mg} / \mathrm{mL}, 9 \mathrm{mg} / \mathrm{mL}, 6 \mathrm{mg} / \mathrm{mL}$ dan $3 \mathrm{mg} / \mathrm{mL}$.

\section{Uji Perusakan Biofilm}

Uji perusakan biofilm dilakukan pada 4 sampel bakteri yaitu isolat $A$, isolat $B$, isolat $C$, isolat $D$, masing-masing isolat diulang triplo. Sebanyak $100 \mu \mathrm{L}$ suspensi bakteri $10^{6}$ $\mathrm{CFU} / \mathrm{mL}$ dimasukkan ke dalam well pada plat mikrotiter beserta $100 \mu \mathrm{L}$ media TSBglu, kemudian plat mikrotiter diinkubasi pada suhu $37{ }^{\circ} \mathrm{C}$ selama dua hari (telah terbentuk biofilm). Setelah dua hari, suspensi dibuang dan well dicuci dengan air mengalir sebanyak 3 kali. Selanjutnya ditambahkan $200 \mu \mathrm{L}$ sampel fraksi etil asetat dengan dosis $15 \mathrm{mg} / \mathrm{mL}, 12 \mathrm{mg} / \mathrm{mL}, 9 \mathrm{mg} / \mathrm{mL}, 6$ $\mathrm{mg} / \mathrm{mL}$, dan $3 \mathrm{mg} / \mathrm{mL}$ pada well. Sebagai "Kontrol negatif" adalah well berisi bakteri yang diberi larutan DMSO 10\% (tanpa fraksi etil asetat). Perlakuan tersebut diulang pada 2 plat mikrotiter, 1 plat diinkubasi selama 1 jam dan 1 plat diinkubasi selama 2 jam. Setelah diinkubasi, cairan dibuang. Plat mikrotitter dicuci dengan PBS $200 \mu \mathrm{L}$. Kemudian ditambahkan $200 \mu \mathrm{L}$ kristal violet $0,1 \%$ ke dalam setiap well. Didiamkan 15 menit pada suhu ruang. Dicuci dengan air mengalir sebanyak 3 kali. Ditambahkan 200 $\mu \mathrm{L}$ isopropanol $\mathrm{HCl}$ ke setiap well. Selanjutnya dilakukan pembacaan optical density (OD) pada panjang gelombang 630 $\mathrm{nm}$. Persentase kerusakan biofilm dihitung menggunakan rumus sebagai berikut. ${ }^{9}$

\section{$\%$ Kerusakan biofilm =}

$\frac{\text { Nilai OD Kontrol negatif-Nilai OD fraksi }}{\text { Nilai OD Kontrol negatif }} \times 100 \%$

\section{Uji Jumlah Koloni Bakteri}

Diambil dari setiap sumur (suspensi biofilm sebelum dilakukan pewarnaan dengan kristal violet) sebanyak satu ose dan digoreskan pada media Nutrient Agar secara merata di seluruh permukaan media. Kemudian diinkubasi selama 24 jam. Jumlah koloni yang tumbuh dihitung dan diinterpretasikan menggunakan penilaian skor. Skor tertinggi +6 untuk jumlah koloni bakteri yang amat sangat padat, +5 terdapat koloni bakteri yang sangat padat tetapi terlihat jarak antar koloni, +4 terdapat koloni bakteri yang padat dan terlihat jarak antar koloni, +3 terdapat koloni bakteri yang cukup padat dan terlihat jarak antar koloni, +2 terdapat koloni bakteri yang tidak padat dan terlihat jarak antar koloni, +1 terdapat koloni bakteri dengan jumlah yang sangat tidak padat dan jarak antar koloni lebih jauh.

\section{Analisis Data \\ Data yang diperoleh kemudian dianalisis menggunakan uji korelasi Spearman dan Paired t-test dengan tingkat kepercayaan $95 \%(\alpha=0,05)$.}

Hasil

Fraksi Etil Asetat dari Ekstrak Daun Mimosa

Ekstrak daun Mimosa berupa cairan kental berwarna hijau coklat memiliki bau khas aromatik. Hasil rendemen ekstrak adalah sebesar $8,88 \% \mathrm{~b} / \mathrm{b}$, sedang hasil rendemen fraksi etil asetat dari ekstrak adalah $9,47 \%$ b/b.

\section{Identifikasi Bakteri MRSA}

\section{Pewarnaan Gram}

Hasil pewarnaan Gram terhadap sampel bakteri (isolat A, B, C, dan D) menunjukkan gambaran bakteri bentuk kokus berwarna ungu (Gram positip), seperti terlihat pada Gambar 1. 


\section{Uji Katalase dan Uji Koagulase}

Hasil pengamatan uji katalase diperoleh semua isolat bakteri terdapat gelembung udara, dan pada uji koagulase terlihat adanya clumping berwarna putih (Gambar 2).

A

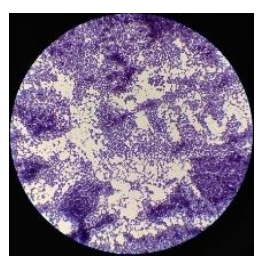

C

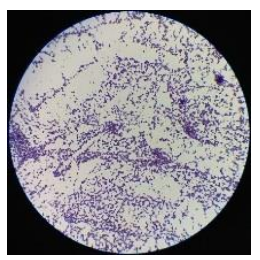

Gambar 1. Pewarnaan Gram.

Keterangan: Terlihat semua isolat bakteri $(A, B, C, D)$ berbentuk kokus Gram positip, perbesaran 1000x.

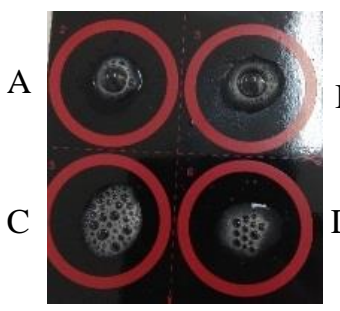

Uji katalase

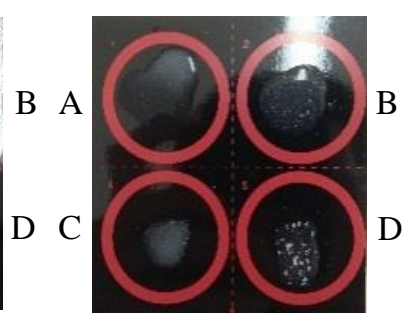

Uji koagulase
Gambar 2. Hasil uji katalase dan uji koagulase bakteri MRSA.

Keterangan: Semua 80solate bakteri $(A, B, C, D)$ menunjukkan katalase positip dan koagulase positip.

\section{Uji Sensitivitas Terhadap Sefoksitin}

Hasil uji sensitivitas terhadap sefoksitin menunjukkan bahwa tidak terbentuk zona hambat pada semua 80solate bakteri (resisten) seperti pada Gambar 3. Dari hasil tersebut dapat diinterpretasikan bahwa 80solate A, 80solate B, 80solate $C$ dan 80 solate $D$ adalah bakteri MRSA.
A

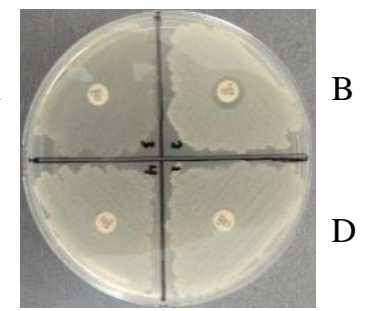

Gambar 3. Hasil uji sensitivitas terhadap cefoxitin

Keterangan: Tidak terbentuk zona hambat pada semua isolat bakteri $(A, B, C, D)$ (resisten terhadap sefoksitin).

\section{Hasil Uji Kerusakan Biofilm}

Hasil uji kerusakan biofilm dengan inkubasi 1 jam dan 2 jam menunjukkan bahwa terjadi peningkatan kerusakan seiring dengan peningkatan dosis fraksi etil asetat ekstrak daun Mimosa seperti ditunjukkan pada Gambar 4.

Dari Gambar 4. tersebut, dapat dilihat bahwa secara deskriptif ada perbedaaan hasil persen kerusakan biofilm, baik terhadap dosis maupun waktu. Berdasarkan hasil persen degradasi biofilm terhadap waktu pada bakteri Methicillin-Resistant Staphylococcus aureus (MRSA), pada perlakuan 1 jam diperoleh hasil persen degradasi tertinggi hingga terendah berturutturut yaitu dosis $15 \mathrm{mg}$, dosis $12 \mathrm{mg}$, dosis 9 $\mathrm{mg}$, dosis $6 \mathrm{mg}, 3 \mathrm{mg}$ (Spearman, $r=0,426$, $p=0,01$ ); sedangkan untuk waktu 2 jam tidak ada perbedaan bermakna antara perlakuan dosis (Spearman, $r=0,142, p=$ 0,278 ). Berdasarkan perbedaan perlakuan waktu, terlihat bahwa degradasi bioflm pada perlakuan waktu 2 jam lebih tinggi dibanding waktu 1 jam untuk semua macam dosis (Paired $t$ test, semua dosis menunjukkan $p<$ $0,00)$ (Lihat Gambar 4).

\section{Hasil Perhitungan Jumlah Koloni}

Dari hasil perhitungan jumlah koloni yang tumbuh, pada perlakuan dengan inkubasi 1 jam maupun 2 jam terjadi penurunan jumlah koloni seiring dengan 
peningkatan dosis seperti ditunjukkan pada Gambar 5. Hasil analisis statistik perlakuan 1 jam menunjukkan penurunan jumlah koloni seiring dengan peningkatan dosis (Spearman, $r=-0,509, p=0,022$ ). Untuk perlakuan waktu 2 jam, menunjukkan penurunan jumlah koloni yang tidak bermakna (Spearman, $r=-0,389, p=$ 0.093). Tidak ada perbedaan yang signifikan antara jumlah koloni padaperlakuan waktu 1 jam dengan 2 jam (Paired $t$ test, semua dosis menunjukkan $p>$ $0,00)$.

\section{Pembahasan}

Pada penelitian ini, dimaksudkan untuk mendapatkan informasi terkait daun putri malu (Mimosa pudica) dapat digunakan sebagai perusak biofilm yang dibentuk oleh bakteri Methicilin-Resistant Staphylococcus aureus (MRSA). Selain itu, pada ekstraksi maserasi tidak ada pemanasan sehingga senyawa aktif tidak menjadi terurai. ${ }^{10}$ Pemilihan pelarut etanol $96 \%$ digunakan karena kemampuan etanol yang bagus dalam melarutkan senyawa semipolar di antaranya flavonoid.

Untuk menarik senyawa flavonoid dari ekstrak, selanjutnya dilakukan fraksinasi menggunakan pelarut etil asetat setelah sebelumnya digunakan $n$-heksan. Dengan fraksinasi ini, akan terpisahkan senyawa berdasarkan tingkat kepolaran yang berbeda karena menggunakan dua pelarut yang memiliki tingkat kepolaran yang berbeda. ${ }^{11,12}$

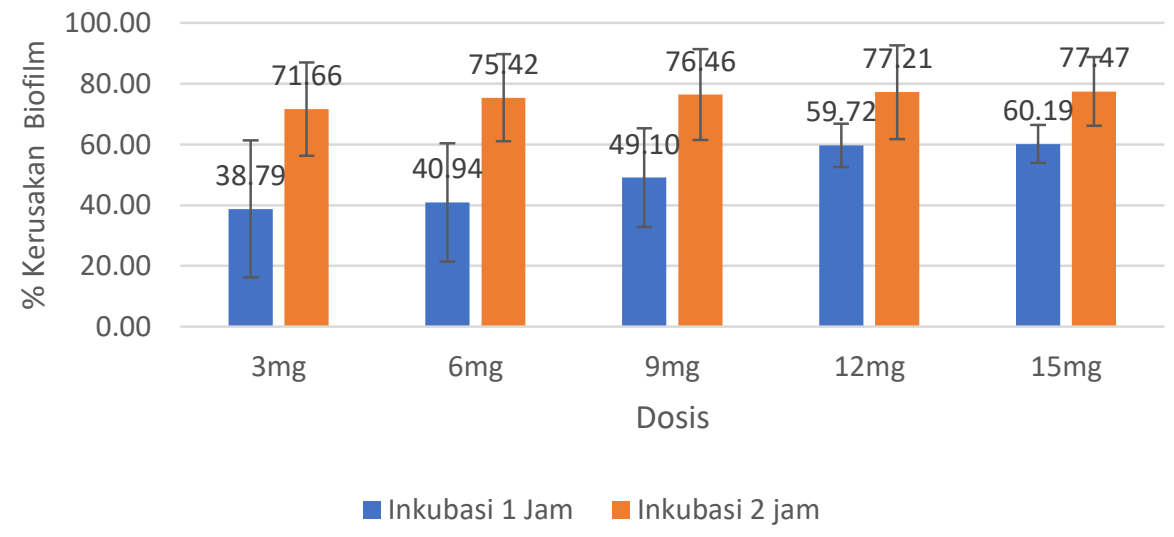

Gambar 4. Diagram persentase kerusakan biofilm.

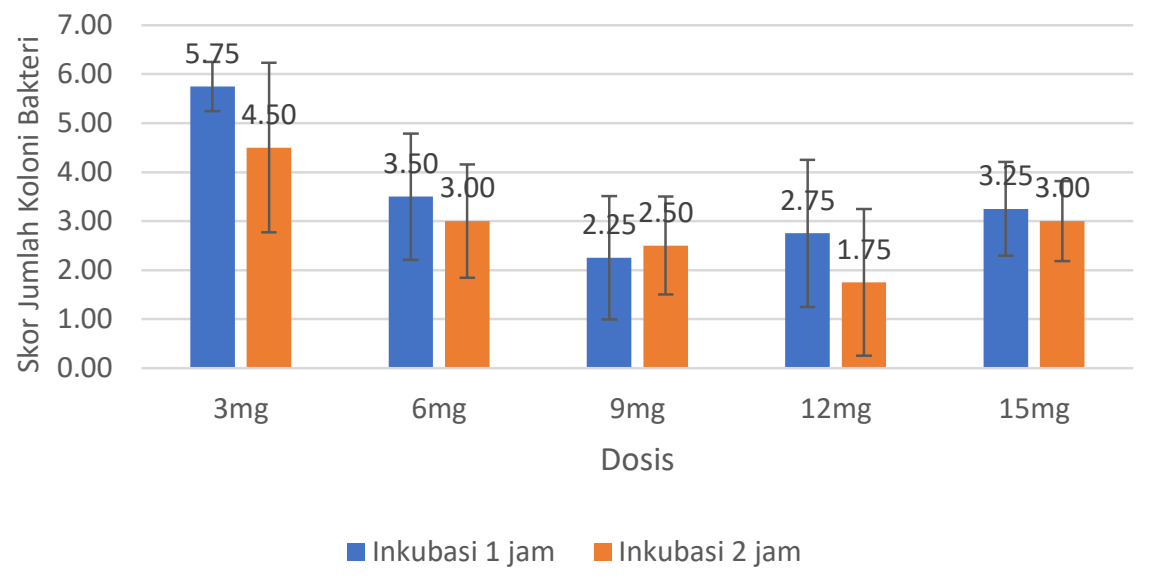

Gambar 5. Diagram jumlah koloni bakteri berdasarkan penilaian skor. 
Pada penelitian sebelumnya dilaporkan bahwa fraksi etil asetat dari ekstrak daun putri malu (Mimosa pudica) mengandung senyawa flavonoid dan alkaloid. ${ }^{13}$

Pada penelitian ini, yang digunakan sebagai sampel adalah bakteri MRSA dari penderita yang mengalami luka infeksi, sehingga dapat menggambarkan efek mimosa terhadap MRSA di klinik. Pada uji koagulase, bakteri sampel menunjukkan koagulase positif karena terjadi penggumpalan (clumping) seperti yang ditunjukkan pada Gambar 3. Menurut Andreasen ${ }^{14}$, Bakteri stafilokokus yang menghasilkan enzim koagulase diinterprretasikan sebagai true pathogen dan disebut sebagai Staphylococcus aureus, sedangkan stafilokokus koagulase negatif biasanya sebagai patogen oportunistik. ${ }^{14,15}$ Koagulase adalah salah satu faktor virulensi dari Staphylococcus, merupakan protein yang serupa dengan enzim dan memiliki kemampuan untuk menggumpalkan plasma dengan bantuan faktor yang terdapat pada serum. ${ }^{16}$ Selain itu, bakteri stafilokokus menggunakan enzim katalase untuk dapat melindungi diri dari hidrogen peroksida $\left(\mathrm{H}_{2} \mathrm{O}_{2}\right)$ dengan cara mengubahnya menjadi air dan oksigen. ${ }^{17}$ Untuk identifikasi bakteri Methicillin-Resistant Staphylococcus aureus, saat ini menggunakan uji resistensi terhadap antibiotika sefoksitin. Pada uji sensitivitas terhadap sefoksitin, diketahui bahwa semua isolat sampel resisten terhadap sefoksitin (zona hambat $<21 \mathrm{~mm}$ ), sehingga disimpulkan bahwa semua isolat bakteri sampel adalah bakteri MRSA. MRSA adalah bakteri Staphylococcus aureus yang bersifat multiresisten terhadap berbagai jenis antibiotika sehingga sering menimbulkan masalah pengobatan terhadap penyakit infeksi. ${ }^{7,18}$

Uji perusakan biofilm pada penelitian ini dilakukan dengan menggunakan metode mikrodilusi menggunakan plat mikrotitter. Metode mikrodilusi tepat digunakan apabila fraksi/senyawa yang ingin diuji jumlahnya terbatas, namun jenis mikroorganisme atau variabel yang diujikan tetap dapat beragam. Keuntungan dari metode mikrodilusi ini adalah mudah dilakukan, serta memberikan efisiensi dalam segi bahan dan peralatan. ${ }^{19}$

Berdasarkan persentase kerusakan biofilm, hasil penelitian ini menunjukkan terdapat hubungan antara dosis dengan peningkatan perusakan biofilm. Pada dosis terendah yaitu $3 \mathrm{mg}$, fraksi etil asetat sudah memberikan efek perusakan biofilm dan meningkat seiring dengan peningkatan dosis. Hasil peneltian ini juga menunjukkan bahwa waktu inkubasi yang lebih lama akan menghasilkan persentase kerusakan yang lebih tinggi.

Pada penelitian ini, fraksi etil asetat ekstrak daun Mimosa dengan dosis $3 \mathrm{mg}, 6$ $\mathrm{mg}, 9 \mathrm{mg}, 12 \mathrm{mg}$, dan $15 \mathrm{mg}$ secara deskriptif menunjukkan efek membunuh bakteri yang didalam biofilm (jumlah koloni yang tumbuh menurun seiring dengan meningkatnya dosis), namun terlihat kurang konsisten sehingga kekuatan hubungan antara dosis dan efek rendah. Pada Gambar 5 , dapat dilihat bahwa perlakuan dosis 3 $\mathrm{mg} / \mathrm{mL}, 6 \mathrm{mg} / \mathrm{mL}$, dan $9 \mathrm{mg} / \mathrm{mL}$ jelas menunjukkan penurunan jumlah koloni bakteri yang tumbuh, sedangkan pada dosis $12 \mathrm{mg} / \mathrm{mL}$ dan $15 \mathrm{mg} / \mathrm{mL}$ terlihat jumlah koloni yang lebih tinggi meskipun tidak berbeda bermakna dengan dosis $9 \mathrm{mg} / \mathrm{mL}$. Hasil yang menunjukkan efek antibakteri tersebut sesuai dengan penelitian Kamelia ${ }^{13}$ yang melaporkan bahwa fraksi etil asetat memiliki aktivitas antibakteri terhadap MRSA. Dengan demikian, berdasarkan hasil penelitian ini dapat dibuktikan bahwa fraksi etil asetat ekstrak daun Mimosa mampu merusak biofilm, dan membunuh bakteri yang berada didalam lapisan biofilm.

Pada Gambar 5, dapat dilihat pula bahwa efek membunuh bakteri pada perlakuan waktu inkubasi 1 jam tidak ada perbedaan dengan waktu inkubasi 2 jam. Hal 
ini kemungkinan disebabkan pengamatan jumlah koloni yang sangat kasar yaitu menggunakan skoring yang dipengaruhi oleh subyektivitas yang mengamati, sehingga menghasilkan standar deviasi (SD) yang sangat lebar membuat secara statistik tidak berbeda bermakna. Untuk itu, disarankan dilakukan penelitian serupa dengan metode yang lebih objektif yaitu dilakukan pengenceran sebelum dikultur agar jumlah koloni dapat terhitung, sehingga didapatkan data yang lebih baik untuk dianalisis. Kemungkinan yang lain adalah fraksi etil asetat ekstrak daun Mimosa belum optimal dalam merusak biofilm sehingga masih banyak bakteri yang terlindungi oleh biofilm dan tumbuh saat dikultur.

Beberapa penelitian yang menggunakan ekstrak herbal atau fraksinya, menunjukkan hasil yang positif yaitu ekstrak herbal mampu menghambat pembentukan maupun merusak biofilm bakteri. Pada penelitian yang telah dilakukan Mutmainah dkk. ${ }^{20}$, efektivitas ekstrak etanol Mimosa pudica terhadap pembentukan biofilm bakteri Staphylococcus aureus menunjukkan hasil bahwa adanya penurunan nilai rerata pembentukan biofilm dimulai pada konsentrasi $50 \mathrm{mg} / \mathrm{mL}$ dan meningkat seiring bertambahnya konsentrasi. Menurut penelitian Yuliandari21 yang juga menguji aktivitas degradasi biofilm dari sari buah belimbing wuluh terhadap bakteri Pseudomonas aeruginosa menunjukkan bahwa semakin besar konsentrasi ekstrak yang digunakan maka semakin besar degradasi biofilm yang terjadi. Meskipun ekstrak herbal potensial sebagai bahan antibiofilm, namun bahan berupa ekstrak mengandung banyak senyawa aktif sedangkan bahan berupa fraksi hanya mengandung beberapa senyawa aktif. Dengan demikian, uji antibiofilm menggunakan fraksi ekstrak herbal akan lebih mudah dilakukan standarisasi dosis untuk aplikasinya di klinik.
Menurut penelitian yang telah dilakukan oleh Kamelia ${ }^{13}$, diketahui bahwa fraksi etil asetat ekstrak etanol daun putri malu (Mimosa pudica) mengandung senyawa metabolit sekunder flavonoid. Menurut Lee et al. 5 , senyawa flavonoid memiliki potensi menghambat intercellular adhesion genes icaA dan icaD. Gen icaA dan icaD adalah gen penyandi protein yang memperantarai perlekatan antar sel bakteri, sehingga menjadi salah satu faktor dari pembentukan biofilm. Flavonoid juga memiliki aktivitas dalam merusak biofilm. Mekanisme flavonoid sebagai agen yang dapat merusak biofilm adalah dengan cara gugus hidroksil pada struktur flavonoid berikatan dengan protein yang ada dalam biofilm dan membentuk senyawa kompleks yang menyebabkan biofilm terdenaturasi. ${ }^{6}$ Selain itu, flavonoid juga disebutkan memiliki efek antibakteri. Aktivitas flavonoid dalam membunuh bakteri yaitu dengan menghambat sintesis asam nukleat, serta mengganggu fungsi membran sel dan metabolisme energi.22,23 Flavonoid menunjukkan aktivitas menghambat sintesis asam nukleat yaitu pada cincin $A$ dan cincin $B$ dalam proses interkalasi dalam ikatan hidrogen, menghasilkan penumpukan basa nukleat, dengan akibat hambatan pembentukan DNA dan RNA bakteri. Flavonoid juga dapat menyebabkan kerusakan permeabilitas dinding sel bakteri, mikrosom maupun lisosom. ${ }^{23}$ Mekanisme kerja flavonoid dalam menghambat fungsi membran sel adalah membentuk senyawa kompleks dengan protein ekstraseluler dan terlarut sehingga merusak membran sel

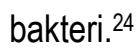

Berdasarkan pada penelitian yang dilakukan oleh Kamelia ${ }^{13}$, diketahui bahwa selain flavonoid, juga terdapat senyawa alkaloid yang tertarik pada fraksi etil asetat. Alkaloid juga menunjukkan aktivitas antibakteri. Mekanisme alkaloid sebagai antibakteri adalah sebagai interkalator DNA dan menghambat dari enzim topoisomerase 
pada sel bakteri. ${ }^{25}$ Selain itu, mekanisme alkaloid sebagai antibakteri adalah dengan mengganggu komponen penyusun peptidoglikan sehingga peptidoglikan sebagai lapisan penyusun dinding sel bakteri tidak terbentuk secara utuh dan mengakibatkan kematian bakteri. ${ }^{26}$

\section{Kesimpulan}

Berdasarkan hasil penelitian dan pembahasan, disimpulkan bahwa fraksi etil asetat dari ekstrak daun putri malu (Mimosa pudica) mampu merusak biofilm bakteri MRSA, dan waktu inkubasi 2 jam menunjukkan kerusakan biofilm yang lebih tinggi dari pada 1 jam. Fraksi etil asetat dari ekstrak daun putri malu juga mampu membunuh bakteri yang membentuk biofilm, namun tidak ada perbedaan antara waktu inkubasi 1 jam dan 2 jam.

\section{Saran}

Dilakukan penelitian serupa dengan cara penghitungan jumlah koloni secara objektif (dilakukan pengenceran sebelum dikultur) sehingga didapatkan data yang lebih baik untuk dianalisis.

\section{Daftar Pustaka}

1. Chen CJ \& Huang YC. New Epidemiology of Staphylococcus aureus Infection in Asia. Clin Microbiol Infect. 2014; 20(7):605-606.

2. Kurniawati AFS, Satyabakti $P$, Arbianti N. Perbedaan Risiko Multidrug Resistance Organisms (MDROS) Menurut Faktor Risiko dan Kepatuhan Hand Hygiene. Jurnal Berkala Epidemiologi. 2015; 3(3):277-289.

3. Arjuna A, Pratama WP, Sartini, Mufidah. Uji Pendahuluan Antibiofilm Ekstrak Teh Hijau dan Teh Hitam pada Streptococcus mutans Melalui Metode Microtitter Plate.
Jurnal Farmasi Galenika. 2018; 4(1):44 49.

4. Mehingko L, Awaloei $\mathrm{H}$, Wowor MP. Uji Efek Antimikroba Estrak Daun Putri Malu (Mimosa pudica Duchaas \& Walp) Secara In Vitro. Jurnal Biomedik. 2010; 2(1):44-49.

5. Lee J-H, JH Park, HS Cho, SW Joo, MH Cho, J Lee. Antibiofilm Activities of Quercetin and Tannic Acid Against Staphylococcus aureus. Biofouling: The Journal of Bioadhesion and Biofilm Research. 2013; 29(5).

6. Kining E. Aktivitas Antibiofilm Ekstrak Air Daun Melinjo, Daun Singkong, dan Daun Pepaya terhadap Bakteri Pseudomonas aeruginosa secara In Vitro. Tesis. Bogor: Program Studi Biokimia Institut Pertanian Bogor. 2015.

7. Khan F, Shukla I, Rizvi M. Cefoxitin Disc Test as a Marker for Detecting Methicillin Resistence in Staphylococcus aureus Isolates. Journal of Pure and Applied Microbiology. 2010; 4(2):831-835.

8. Murray $P R$, Baron EJ, Pfaller MA, Tenover FC, and Yolken RH. Manual of Clinical Microbiology. $7^{\text {th }}$ Edition. Washington DC: American Society for Microbiology. 1999. Pp. 284.

9. Sandasi LCM, Viljoen AM. The In Vitro Antibiofilm Activity of Selected Culinary Herb and Medical Plants Against Listeria monocytogenes. Letters in Applied Microbiology (50). 2010. P. 30-35.

10. Puspitasari $A D$ dan Prayogo LS. Perbandingan Metode Ekstraksi Maserasi dan Sokletasi Terhadap Kadar Fenolik Total Ekstrak Etanol Daun Kersen (Mutingia calabura). Jurnal IImiah Cendekia Eksakta. 2017.

11. Pratiwi ST. Mikrobiologi Farmasi. Jakarta: Penerbit Erlangga. 2008.

12. Soeksamanto. Mahkota Dewa, Phaleria macrocarpa (Scheff) Boerl. (Thymelaceae) Biodiversita. 2010; 8(2): 92-95. 
13. Kamelia NJ. Aktivitas Antibaktri Fraksi Ekstrak Etanol Daun Putri Malu (Mimosa pudica) Terhadap Methicillin Resistant Staphylococcus aureus (MRSA) Secaraln Vitro. Skripsi. Malang: Fakultas Kedokteran. Universitas Brawijaya. 2018.

14. Andreasen CB. Staphylococcosis dalam Diseases of Poultry. 12 $2^{\text {th }}$ Edition. Saif YM, Fadly AM, McDougald, Nolan, LK, Swayne DE (Editor). USA: Blackwell Publishing. 2008. p 892-896.

15. Yurdakul NE, Erginkaya Z, and Unal E. Antibiotic Resistance of Enterococci, coagulase negative Staphylococci and Staphylococcus aureus Isolated from Chicken Meat. J Food Sci. 2013. 31(1):14 -19.

16. Karimela EJ, ljong FG, Dien HA. Karakteristik Staphylococcus aureus yang Diisolasi dari Ikan Asap Pinekhe Hasil Olahan Tradisional Kabupaten Sangihe. Jurnal Pengolahan Hasil Perikanan Indonesia. 2017. 20(1).

17. Locke T, Keat S, Walker A, Mackinnon R. Microbiology and Infectious Diseases on The Move. Jakarta: Penerbit Indeks. 2013.

18. Clinical and Laboratory Standards Institute. Performance Standards for Antimicrobial Disk Susceptibility Test; Aproved Standard M02-A11. Clinical and Laboratory Standards Institute, Wayne, PA. 2012.

19. Jorgensen JH, Ferraro MJ. Antimicrobial Susceptibility Testing: A Review of General Principles and Contemporary Practices. Clinical Infectious Disease. 2009. 49:1749-55.

20. Mutmainah BQ, Supnawadi, $\mathrm{Ni}$ Matuzahroh. Efektivitas Ekstrak Etanol
Mimosa pudica L. Terhadap Pembentukan Biofilm Staphylococcus aureus. Prosiding Seminar Nasional Pendidikan Biologi. 2018.

21. Yuliandari R. Uji Aktivitas Antibiofilm Sari Buah Belimbing Wuluh (Averrhoa bilimbi L) Terhadap Pseudomonas aeruginosa Secara In Vitro. Skripsi. UIN Syarif Hidayatullah Jakarta: Fakultas Kedokteran dan IImu Kesehatan. 2015.

22. Hendra R, Ahmad S, Sukari A., Shukor, MY, Oskouelan E. Flavonoid Analyses and Antimicrobial Activity of Various Parts of Phaleria macrocarpa (Scheff). Boerl Fruit. Intr J Mol Sci. 2011; 12:34223431.

23. Cushnie TPTim, Lamb Andrew. Journal Antimicrobial Activity of Flavonoids. International Journal of Antimicrobial Agents. 2005; 26:343-356.

24. Nuria MC, Faizaitun, A Sumantri. Uji Aktivitas Antibakteri Ekstrak Etanol Daun Jarak Pagar (Jatropa curcas $L$ ) terhadap Bakteri Staphylococcus aureus ATCC25923, Escherichia coli ATCC 25922, dan Salmonella typhi Atcc 1408. 2009; 2(6):26-37.

25. Karou D, Savadogo A, Canini A, Saydou Y, Monstesano C, Simpore J, et al. Antibacterial Activity of Alkaloids from Sida Acuta. African Journal of Biotechnology. 2005; 4(12):1452-1457.

26. Darsana I, Besung I, Mahatmi H. Potensi Daun Binahong (Anredera codifolia (Tenore) Steenis) dalam Menghambat Pertumbuhan Bakteri Escherichia coli Secara In Vitro. Indonesia Mediscus Veterinus. 2012. 